\title{
Doc. Ing. Tomáš Ježek, CSc.
}

\section{(15. 3. 1940 PIzeň - 29. 11. 2017)}

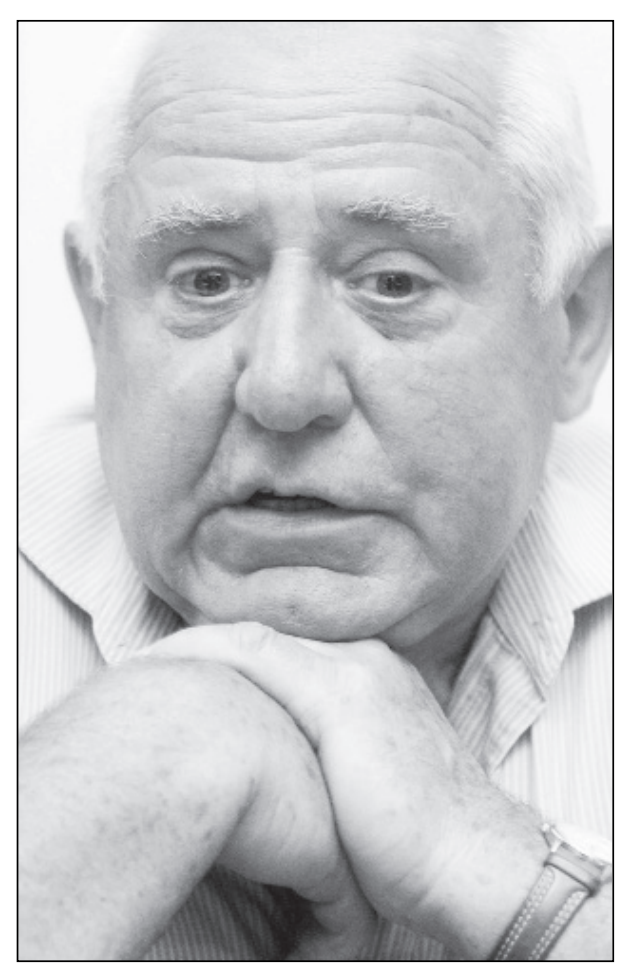

Foto: ČTK / Michal Kamaryt

Koncem listopadu loňského roku skončila pozemská pout Tomáše Ježka, jednoho z nejvýznamnějších českých ekonomů v posledním pưlstoletí, vysokoškolského pedagoga, politika a překladatele.

Ve svých dvaadvaceti letech absolvoval Národohospodářskou fakultu Vysoké školy ekonomické v Praze v oboru ekonomiky práce a $\mathrm{s}$ touto fakultou spojil celou svou akademickou kariéru.

Zahraniční zkušenosti začal získávat již od roku 1965, kdy byl na třítýdenní stáži v tehdejší Německé spolkové republice na Deutscher Akademischer Austaushdienst. V letech 1967-1968 působil v OSN v Evropské hospodářské komisi ve švýcarské Ženevě na Institutu des Hautes Études Internationales. Účastnil se zde speciálních seminářu francouzského vědce Maurice Allaise, nositele Nobelovy ceny za ekonomii z roku 1988. Bylo to v době, kdy se Maurice Allaise, věnující se i prírodním vědám v oblasti gravitace, speciální teorie relativity a elektromagnetismu, začínal soustřed’ovat na teorii rozhodování a měnovou politiku, teorii trhu a efektivní využívání zdrojů. Tomáš Ježek zde navštěvoval také workshopy prof. Sidjanského se zaměřním na problematiku evropské integrace. Mimo jiné spolupracoval i na projektu Evropské hospodářské komise OSN „Prognóza evropské ekonomiky do roku 1980“, v rámci které byla předložena i stat’ o prř́činách poklesu porodnosti $\mathrm{v}$ tehdejším Československu. S největší pravděpodobností to byla právě tato zahraniční stáž, která ho významně ovlivnila při zkoumání tržně konformních liberálních a konzervativních směrů $\mathrm{v}$ ekonomické teorii. Zároveň se začal zabývat možností aplikovatelnosti těchto př́istupů pro hospodářskopolitickou praxi.

V 60. letech působil v Ekonomickém ústavu Československé akademie věd, kde v letech 1966-1969 absolvoval interní aspiranturu. Věnoval se v ní teorii mezd. Toto téma považoval tehdy za mimořádně aktuální, nebot' „nová soustava řízeni““ spoléhala na zainteresovanost na hrubém důchodu (mzdy plus zisky) jako na hybatele hospodáŕského rozvoje. Ve své disertační práci se mu podařilo prokázat, že determinace mezd má svou vnitřní logiku, která významně omezuje možnosti svazovat vývoj mezd s vývojem 
zisků. V 70. a 80. letech minulého století se zabýval teorií plánování, zejména možnostmi jeho racionalizace pomocí tzv. cílového principu. Prokázal, že sledování věcných cílů z úrovně národního hospodářství namísto cílů systémových nemůže zajistit hospodářský rozvoj srovnatelný s tržním hospodářstvím. Koncem 80 . let se soustředil na studium vlastnických práv a jejich významu pro fungování tržního hospodářství. V Ekonomickém ústavu ČSAV zůstal až do konce roku 1985. Odtud pak odešel do Prognostického ústavu Československé akademie věd.

Tomáš Ježek byl jedním z mála ekonomů, který znal podrobně dílo nejvýznamnějšího filozoficko-ekonomického myslitele 20. století Friedricha Augusta von Hayeka. Byl jeho velkým obdivovatelem. Jeho dílo překládal již v 70. a 80. letech minulého století. Oficiálně v té době nemohlo být vydáno, proto se objevovaly pouze části v různých podobách v samizdatových materiálech. Patřil mezi nepočetnou skupinu ekonomů, kteří na konci 80. let minulého století připravovali vědecké studie, které se staly v mnoha ohledech základem pro transformaci české ekonomiky.

Po společensko-politických změnách v listopadu 1989 se stal poradcem tehdejšího ministra financí Václava Klause, se kterým se znal již od dětství. Vázalo je k sobě přátelské pouto a především společný zájem o ekonomii. Po prvních svobodných volbách v roce 1990 se stal prvním ministrem privatizace české vlády v tehdejším Československu a předsedou prezidia Fondu národního majetku. Zároveň vykonával funkci poslance a v letech 1992-1996 byl ve velmi významném postavení předsedy Rozpočtového výboru Poslanecké sněmovny Parlamentu ČR. Byl iniciátorem založení Komise pro cenné papíry, kde působil jako člen prezidia.

Politicky působil v Občanské demokratické alianci a později krátce v Občanské demokratické straně. Během své politické kariéry se pokoušel dvakrát uspět ve volbách do Senátu Parlamentu ČR. Poprvé v roce 1996 za ODS a podruhé v roce 2004 jako nestraník za uskupení LIRA. Tomáš Ježek měl velice široké portfolio svých činností. Byl mimo jiné předsedou parlamentní delegace v OSCE (Organisation for Security and Co-operation in Europe); byl i členem pracovní skupiny pro přípravu Ústavy ČR. Ve druhé polovině 90. let zastával na Burze cenných papírů Praha, a.s., pozici předsedy burzovní komory. V přehledu své vědeckovýzkumné činnosti, který sám koncipoval, spatřoval svůj největší přínos především v oblasti privatizace, kapitálového trhu a jeho regulace a správy a řízení společností kótovaných na veřejných trzích.

Citujeme samotného Tomáše Ježka: „Za svůj prínos v oblasti teorie a praxe privatizace považuji podíl na koncipování kupónové privatizace. V oblasti teorie a praxe kapitálového trhu je mým přinosem legislativní zakotvení ochrany minoritních akcionář̀ do obchodního zákoníku v roce 1996. Tento teoretický a praktický problém byl mimořádně aktuální v obdobi po skončeni kupónové privatizace, která vytvořila velký počet akcionářù s minoritním postavením. Studium teorie správy a řizení akciových společností, které vyústilo do koncipování Kodexu, bylo rovněž motivováno zcela novou a neprobádanou situaci vzniklou vytvořením velkého počtu akciových společností, které všechny hledaly náležitý vztah managementu a akcionárư a akcionářu různé síly navzájem. Zcela neprobádanou oblastí, jak teoreticky, tak prakticky, byl též dozor nad kapitálovým trhem 
a jeho regulace. Moje činnost na tomto poli se dočkala zejména mezinárodního uznání. “ (Ježek, 2006, str. 1)

Některé kroky spojené s ochranou minoritních akcionářů, které Tomáš Ježek prosazoval, musel později korigovat. Č́st minoritních akcionářů se stala tzv. greenmailery a tito se ve své svaté válce $\mathrm{v}$ bojích proti ostatním akcionářům často dopouštěli vyděračských praktik. Koneckonců se celá řada sporů, např. ve věci tzv. squeeze-outů, táhne již déle než dekádu (Liberální institut, 1997). Taktéž Kodex správy a řízení akciových společností doznal později několika úprav. Tomáš Ježek tak jako mnozí ostatní poznal, jak složité bylo převézt ekonomické teorie do reálné hospodářsko-politické praxe. Byl poměrně zklamán i z vývoje kolem dozoru nad kapitálovým trhem a jeho regulací. Sám čelil snahám o odvolání z pozice člena prezidia komise pro cenné papíry, kde však s podporou tehdejšího prezidenta Václava Havla zůstal až do vypršení mandátu v březnu 2002. Tomáš Ježek v souvislosti s privatizací čelil i několika nepravdivým nařčením z podezřelých machinací. Všechny soudy ovšem vyhrál.

Tomáš Ježek byl považován za otce kupónové privatizace. Tuto metodu vehementně obhajoval a k otcovství se hrdě hlásil. Po skončení kupónové privatizace však u něho přveážily negativní postoje $\mathrm{k}$ dalšímu vývoji ve firmách, které touto metodou privatizace prošly. Poukazoval na nedostatečný legislativní rámec, upravující správu a řízení privatizovaných podniků a nedostatečnou regulaci investičních privatizačních fondů, podílových fondů a investičních společností, které se staly rozhodujícími vlastníky naprosté většiny kupónovou metodou privatizovaných firem. Svou kritiku některých transformačních procesů prohloubil v první dekádě 21. století ve své práci Privatizace české ekonomiky: jeji metody, kořeny a výsledky.

S odstupem času lze konstatovat, že v kontextu dosud ojedinělé transformace v moderních světových dějinách šlo o nevelké množství negativních fenoménů souvisejících $\mathrm{s}$ metodou kupónové privatizace. Nelze $\mathrm{v}$ žádném př́padě paušálně odsoudit ani ji samotnou jako metodu ani následný proces fungování zprivatizovaných firem. I z dnešního pohledu se pro realizovaný transformační proces v České republice tato metoda jeví jako jednoznačně nejúspěšnější. Samozřejmě se ji někteří politikové a novináři, často neznalí a neschopní posoudit tento způsob privatizace, snaží kritizovat za každou cenu. Tomáš Ježek se v poslední dekádě svého života ve svých přednáškách, které se týkaly způsobu privatizace v České republice, již nevyjadřoval tak kriticky jako v některých svých písemných textech. V odborné diskusi pak uznával i názory svých oponentů, že ve srovnání s jinými transformujícími se ekonomikami byla česká privatizace nejrychlejší, nejméně nákladnou, nejúspěšnější a dlouhodobě pro ekonomiku nejpřínosnější. V mezinárodním srovnání neměl proti těmto tvrzením téměř žádné argumenty, a tak nakonec těmto tvrzením často přitakal.

Proces zrodu kapitalismu v České republice později Ježek popisoval tak, že vznikal trojím způsobem. První způsob přirovnává k budování kapitalismu na tzv. zelené louce, kdy občané se pustili do podnikání doma, byt' třeba $\mathrm{v}$ paneláku, nebo otvírali své provozovny v garážích, příp. na zahradách a svých záhumencích. Sám konstatoval, že v této formě budování kapitalismu se neangažoval. Druhý způsob vzniku kapitalismu se dle něj 
týkal restitucí a třetí samotné privatizace. K těmto dvěma zpo̊sobům se vždy hrdě hlásil a tvrdil, že je měl i ,určitou dobu pod palcem“.

Tomáš Ježek chtěl navázat na podnikání a podnikatelské prostředí, které u nás bylo za první republiky. Domníval se, že i přes delší časový odstup je na co navazovat a je co obnovovat. Za základ budování kapitalismu považoval obnovení institutu soukromého vlastnictví. Byl hrdý na to, že se mu podařilo protlačit bez projednávání v Legislativní radě vlády během pár měsíců zákon o restitucích, který byl schválen již 1. listopadu 1990.

Celá 90. léta se věnoval budování kapitálového trhu v České republice a popularizaci transformace, zvláště pak privatizace formou přednášek v zahraničí. Vystupoval tak opakovaně ve Francii, Japonsku, v bývalých zemích Jugoslávie, Německu, Norsku, Rakousku, Španělsku, Švédsku, Velké Británii, ale i v Nikaragui či Kazachstánu. Nejvíce přednášek měl v USA, kde k této problematice jenom v 90. letech promluvil sedmkrát.

Tomáš Ježek vystupoval na mnoha domácích i zahraničních konferencích, stál u zrodu Liberálního institutu a Občanského institutu, byl dlouholetým členem Vědecké rady Národohospodářské fakulty VŠE v Praze. Byl mimo jiné i členem řady mezinárodních odborných společností, redakčních rad a organizací, např. The Foundation for a Civil Society, New York - Praha, člen expertních týmů OECD pro správu a řízení v Asii, Rusku a jihovýchodní Evropě, členem Euroshareholders - Evropská asociace národních asociací akcionářů v Bruselu, členem CECGA - Central European Corporate Governance Association v Bratislavě, expertem US AID v Bosně a Hercegovině a v Kazachstánu, předsedou správní rady Nadace Českého hudebního fondu, prezidentem Asociace finančních zprostředkovatelů a finančních poradců ČR, soudním znalcem jmenovaným Městským soudem v Praze v oboru veřejné finance, bankovnictví a kapitálový trh a další.

Tomáš Ježek přednášel téměř dvě desetiletí na Národohospodářské fakultě VŠE a své studenty nadšeně a s hlubokou znalostí věci seznamoval především s dílem Friedricha Augusta von Hayeka, nositele Nobelovy ceny za ekonomii. Mezi studenty byl oblíbený pro svou snahu vysvětlit všechny záhady ekonomie co nejsrozumitelnějším způsobem a také pro svou laskavost, kterou projevoval při jejich zkoušení.

Často vzpomínal, jak byl formován již v 80. letech Hayekovým dílem. Vedle samizdatového překladu Road to Serfdom (1944), do češtiny překládané jako Cesta do nevolnictvi či Cesta do otroctví, byl ovlivněn především Hayekovou prací Právo, zákonodárství a svoboda (Law, Legislation and Liberty, 3 volumes, 1973). Překlad tohoto díla dokončil ještě v roce 1989 a čerpal z něj i ideové impulzy pro realizaci transformačního procesu.

Za Ježkovo ekonomické vyznání může sloužit jeho předmluva k významnému dílu F. A. Hayeka Kontrarevoluce vědy s podtitulem Studie o zneužívání rozumu (The Counter revolution of science: Studies on the abuse of reason, 1952). Tomáš Ježek tuto předmluvu nazval Předmluva jedné oběti kontrarevoluce vědy, v níž čtenářưm sděluje, že když za svých akademických časů studoval a překládal Hayeka, byl to pro něj silný intelektuální zážitek. Nemohl však tušit, že ho čeká zážitek daleko silnější, že bude moci prožít hayekovské drama pyšného rozumu na vlastní kůži. ,,Jako ministr privatizace jsem byl postaven před úkol, který by podle všeho snad ani neměl mít řešení, totiž uvědomělým řizením, administrativním procesem přvézt na svět spontánní řád trhu. Není snad 
paradoxnějšího úkolu. Věděl jsem, že nebudu mít žádnou oporu ani v uvědoméle vytvořeném řádu centrálního plánování, nebot ten již prestával existovat, ani ve spontánním řádu trhu, nebot' ten mél teprve vzniknout. Jediným únikem z tohoto problému byla abstrakce. Aby bylo možné zvládnout úkol vyrobit z beztvaré masy státního majetku tisíce dobře definovaných soukromých vlastnikư, bylo nutné odhlédnout od bezpočtu dưležitých jednotlivostí, právě od těch, které by spontánni řád trhu uměl do hry zapojit. Každodenně se mi potvrzovala hayekovská teze o nekonečné nadřazenosti spontánního řádu nad uvědomělým řízením. Moje zkušenost s uvědomělým řizením veškerého společenského procesu nejenže experimentálně prověrila pravdivost Hayekovy skepse ohledně moci lidského rozumu, ale je též argumentem, proč rozšírit tuto skepsi ještě dále o skepsi ohledně schopnosti lidí učit se jinak než trpkou vlastní zkušeností. “ (Ježek, 1995, str. 7-8)

Podle Tomáše Ježka F. A. Hayek zcela jasně ukázal, že vědci v přírodních vědách, kteří jsou opojeni úspěchem při spoutávání páry nebo v přinucení těles těžších vzduchu létat, mají ambice ř́dit společnost podle předem stanoveného plánu. Tyto jejich snahy však končí neúspěchem nebo přímo katastrofou. Tomáš Ježek tvrdí, že: „Někteři bud' nevědi, že něco jako spontánní řád trhu vỉbec existuje, a ti poněkud osvícenějši to sice tuší, ale o to urputněji proti trhu útočí, protože se na něj přece nemůžeme spoléhat, když to není produkt ničího rozumného uvážení. “ (Ježek, 1995, str. 8).

Tomáš Ježek tyto své myšlenky před více než dvěma dekádami doplnil: „,My v Čechách jsme Hayekovo včasné varování neslyšeli a museli jsme si projít trpkou zkušeností socialismu. Ale máme ji na rozdíl od Západoevropadů a Američanů každopádně za sebou. Na přiště bychom snad měli být vioči vábení sociálních inženýrů imunní. " Tomáš Ježek dodává: ,,alespon̆ na nějakou dobu, alespoň trochu. “ Jak poučné pro dnešní vývoj, a to nejen v eurokritické Evropě, ale i v obamovské a postobamovské Americe.

Mezi jeho poslední publikační počiny patří vydání souboru překladů v roce 2014 pod názvem Liberální ekonomie, kořeny euroamerické civilizace. V této antologii vychází překlady čtyř děl F. A. Hayeka a po jednom od Miltona Friedmana, Gerharda W. Ditzeho, Fritze Machlupa, Ludwiga M. Lachmanna, Michaela Novaka a Herberta A. Simona. Tomáš Ježek spojuje díla těchto autorů s ,kusem“ své osobní historie. Všechny práce považuje za „hledání pravdy o společnosti svobodných lidí“. Vyznává se i z toho, proč s překládáním těchto děl začal. „Byl to sillicí pocit osobni odpovědnosti za mladé lidi, kteři vstupovali do ekonomické vědy s pocitem ztraceného školního času a potřeby zbavit se závaži falešného vzdělání. Byla to i bojová nálada Dona Quijota postavit hráz nesmyslným lžím, nudě a ošklivosti, které se na nás vyřinuly z kanálu etablovaného společenskovědního výzkumu, a pak ode všech dalšich socialistických intelektuáli̊, kteři vyškolení v různých vumlech, plodili k nerozeznání stejné hlouposti v nekonečných debatách o zdokonalování centrálního ř́zení - na všech těch skličujicich zakouřených poradách, na nástěnkách továren, úr̆adi̊ a vojenských útvarů. Ti všichni ničili myšlení lidí všudypřitomnými hesly, útočili na bezbranné ze skleněné obrazovky televize a vytváreli zoufale smutnou atmosféru socialistického duchovniho života. “ (Ježek, 1995, str. 9)

Tomáš Ježek si všiml i agresivity a nenávistnosti marxismu-leninismu a nebezpečného trendu vypůjčování si vědeckého lesku z moderní západní ekonomie. Všímal si 
toho, že mnoho „mladých lidí, vstupujicich tehdy do ekonomické vědy, se dalo nachytat na ,rudou neoklasiku', plnou prvnich derivací a dvojitých integrálů!" A těmto tendencím chtěl Tomáš Ježek postavit hráz svými překlady klasiků tržně konformního myšlení.

V roce 2002 vydal knihu Penize a trh. Měl ambici hledat odpověd' na hypotézu o slabinách ve znalosti peněz a trhu, které se dají předpokládat u občanů, kteří nejsou prrímo ekonomy, ale jsou pracovníky v př́buzných společenskovědních oborech, jako je politologie, filozofie, historie, sociologie či psychologie. Nabízel čtenářům pohled pod pomyslný „zadní kryt tržní ekonomiky“. Chtěl čtenáře seznámit s procesy, které na trhu probíhají, a vysvětlit důvody, proč není dobré nahrazovat tyto složité, často zdánlivě tápající tržní procesy plné výkyvů př́mým direktivním rozhodováním a centrálním plánováním a zda je možné mít tyto procesy více „V ruce“ a řídit je. Vycházel z toho, že mnoho lidí je přesvědčeno, že za složitostí a nedohledností ekonomických procesů, které na trhu probíhají, musí být nějaký velký a všemocný manipulátor, a ještě $\mathrm{k}$ tomu se zlými úmysly. Tomáš Ježek se $\mathrm{v}$ této knize snaží populárním jazykem vysvětlit, jak se lidé rozhodují za situací, které jsou souhrnným výsledkem rozhodování mnoha subjektů, jak se vzájemně ovlivňují makroekonomické veličiny, např. celková poptávka, cenová hladina, celková nabídka, a jakou úlohu při tom hrají peněžní faktory. Tomáš Ježek i v této knize poukazuje na snahu řady ekonomů vytvářet složité modely, ježý neodrážejí procesy v reálné ekonomice. Píše, že mnozí ekonomové si stále libují „v jazyce dvojitých integrálů a rovnic, do nichž nelze dosadit, a spokojí se s komunikací uvnitř úzkého oborového ghetta“. Sám chtěl svou knihou Penize a trh vše, co víme o trhu a penězích, „vyvést ze světa odborníků ven“. Tomáš Ježek věřil, že je to možné bez újmy na pravdivosti a věrnosti sdělení. I když tuto knihu psal před více než dvěma dekádami, není na jejích závěrech nutné měnit vůbec nic. Dostál tak požadavku, který formuloval slavný rakouský filozof K. P. Liessmann, že vědecké teorie mají být srozumitelnou formou vysvětlovány i všem neodborníkům.

Na Tomáše Ježka mám i osobní vzpomínku. Na půdě Ekonomického ústavu jsme v polovině osmdesátých let minulého století společně vedli seminář a diskusi na téma Vztah Friedricha Augusta von Hayeka k centrálnímu plánování. Samozřejmě se naše zásadně odmítavé postoje $\mathrm{k}$ centrálnímu plánování nadřízeným vůbec nelíbily - oba jsme na svých pracovištích dostali výtku za revizionismus, oportunismus, opěvování kapitalismu a pomlouvání socialismu.

Tomáš Ježek byl za své celoživotní dílo a práci oceněn vyznamenáním Crans Montana Forum, Švýcarsko - Prix de la Fondation 1999 za úsilí o transparentnost kapitálového trhu (spolu s panem Černomyrdinem z Ruska, s paní Rugovou z Albánie a panem Jacksonem z USA).

Tomáš Ježek se nesmazatelně zapsal nejen do povědomí všech liberálně tržně konformně smýšlejících ekonomů, ale také zanechal svou stopu u široké veřejnosti, která s ním společně prožila euforii doprovázející počátek transformující se ekonomiky.

Čest jeho památce.

Miroslav Ševčik děkan Národohospodářské fakulty VŠE v Praze 


\section{Literatura}

Ježek, T. (2002). Peníze a trh. Praha: Portál. ISBN 80-7178-685-3.

Ježek, T. (2006). Privatizace české ekonomiky. Její kořeny, metody a výsledky. Př́bram: SEPTIM TISK Príbram. ISBN 80-245-1069-3.

Ježek, T. (2006). Přehled vědeckovýzkumné činnosti. Podklady pro zahájení profesorského řízení na NF VŠE, Praha.

Ježek, T. (2014). Liberální ekonomie. Kořeny euroamerické civilizace. Praha: PROSTOR, pp. 9-10. ISNB 978-80-7260-303-9.

Hayek, F. A. (1995). Kontrarevoluce vědy. Praha: Liberální institut, pp. 7-8. ISBN 80-85787-87-3. Liberální institut (1997). Vývoj českého kapitálového trhu ve střednědobém horizontu. Záznam z diskusního fóra. Praha: Grada Publishing, 1. vydání, pp: 4-6. ISBN 80-7169-520-3. 